\title{
Originals
}

\section{Prevention of autoimmune diabetes in NOD mice by 1,25 dihydroxyvitamin $D_{3}$}

\author{
C.Mathieu ${ }^{1}$, M. Waer ${ }^{2}$, J. Laureys ${ }^{1}$, O. Rutgeerts ${ }^{2}$, R. Bouillon ${ }^{1}$ \\ ${ }^{1}$ Laboratory for Experimental Medicine and Endocrinology, Catholic University of Leuven, Leuven, Belgium \\ ${ }^{2}$ Laboratory of Immunopathology, Rega Institute, Catholic University of Leuven, Leuven, Belgium
}

\begin{abstract}
Summary 1,25 dihydroxyvitamin $D_{3}$, the active form of vitamin $\mathrm{D}$, has immunomodulatory properties in vitro and in vivo. We report that treatment with 1,25 dihydroxyvitamin $\mathrm{D}_{3}(5 \mu \mathrm{g} / \mathrm{kg}$ on alternate days) prevents the development of clinical diabetes in NOD mice, an animal model of human autoimmune diabetes. Diabetes incidence in female NOD mice at the age of 200 days was reduced to $8 \%$ in the 1,25 dihydroxyvitamin D treated group vs $56 \%$ in the control group $(p<0.0001)$. In parallel, treatment with 1,25 dihydroxyvitamin $\mathrm{D}_{3}$ resulted in a complete normalisation of the capacity to induce suppressor mechanisms in an autologous MLR, which is severely depressed in control NOD mice. The existence of such suppressor cells was confirmed in transfer experiments, whereby cotransfer of splenocytes from 1,25 dihydroxyvitamin $D_{3}$ treated NOD mice prevented diabetes transfer by splenocytes
\end{abstract}

from diabetic NOD mice into irradiated, 6-8-week-old male NOD mice. Other known immune defects of the NOD mice, such as defective natural killer cell killing of YAC-1 targets and defective thymocyte activation by anti-CD3 were not corrected. The pharmacological doses of 1,25 dihydroxyvitamin $\mathrm{D}_{3}$ were universally well tolerated as reflected by a normal weight gain of the mice. Serum calcium was increased $(2.5 \pm 0.2$ vs $2.2 \pm 0.2 \mathrm{mmol} / \mathrm{l}$ in the control group, $p<0.005$ ), whereas osteocalcin levels nearly doubled and bone calcium content was halved. These findings show that 1,25 dihydroxyvitamin $\mathrm{D}_{3}$ can prevent diabetes in NOD mice, probably through the correction of their defective suppressor function. [Diabetologia (1994) 37:552-558]

Key words Autoimmunity, immunotherapy, suppressor cells, insulitis, vitamin D analogues
The NOD mouse is an animal model for human autoimmune diabetes (IDDM or juvenile diabetes), characterized by destruction of the insulin producing beta cells of the islets of Langerhans in the pancreas. The precise immune mechanisms leading to this destruction remain unclear [1-3]. Defective elimination of autoreactive T-cell clones or impaired suppressor mechanisms are the most acceptable hypotheses [4]. Conse-

Received: 21 October 1993

and in revised form: 27 December 1993

Corresponding author: Dr. R. Bouillon, Legendo, U.Z. Gasthuisberg, Herestraat 49, B-3000 Leuven, Belgium

Abbreviations: $1,25(\mathrm{OH})_{2} \mathrm{D}_{3}, 1,25$ dihydroxyvitamin $\mathrm{D}_{3}$; NOD, non-obese-diabetic; MLR, mixed lymphocyte reaction; ${ }^{60} \mathrm{Co}, \mathrm{co}-$ balt; ${ }^{51} \mathrm{Cr}$, sodium chromate; SI, stimulation index; NK, natural killer quently, prevention of the disease might be achieved through immunomodulation, preferentially by drugs that are able to block effector T lymphocytes or stimulate suppressor function. Both capacities have been attributed to $1,25(\mathrm{OH})_{2} \mathrm{D}_{3}$, the activated form of vitamin $\mathrm{D}$ [5-6]. Receptors for $1,25(\mathrm{OH})_{2} \mathrm{D}_{3}$ have been described in cells of the immune system [7-8].

In vitro, $1,25(\mathrm{OH})_{2} \mathrm{D}_{3}$ suppresses both effector $\mathrm{T}$ lymph 6 cyte proliferation [9] and lymphokine secretion (interleukin-2, interferon $\gamma$ and tumour necrosis factor $\alpha$ ) [10-13] and it enhances suppressor function [14]. Also in vitro, monocyte differentiation and macrophage function are stimulated, but data on effects of $1,25(\mathrm{OH})_{2} \mathrm{D}_{3}$ on monokine production and accessory cell function are still inconclusive [15-16]. In vivo, $1,25(\mathrm{OH})_{2} \mathrm{D}_{3}$ is able to prevent autoimmune diseases such as experimental allergic encephalomyelitis and allergic thyroiditis [17-18]. A major problem remaining 
however, is the hypercalcaemia induced by the pharmacological doses of this hormone/vitamin, required to obtain these effects. Therefore, most in vivo treatment protocols are short term and deal with experimentallyinduced diseases. In a pilot experiment we demonstrated that $1,25(\mathrm{OH})_{2} \mathrm{D}_{3}$ can prevent insulitis, the histopathological lesion of spontaneous autoimmune diabetes, in NOD mice. The long-term treatment with pharmacological doses of $1,25(\mathrm{OH})_{2} \mathrm{D}_{3}(5 \mu \mathrm{g} / \mathrm{kg})$ was well tolerated when the drug was administered on alternate days and when the animals were fed a low calcium diet [19]. However, the exact mode of action of the substance in the prevention of autoimmunity remains unclear.

The aim of this study was to evaluate the effects of $1,25(\mathrm{OH})_{2} \mathrm{D}_{3}$ on the incidence of clinical diabetes in the NOD mouse and to investigate the immune effects of long-term treatment with $1,25(\mathrm{OH})_{2} \mathrm{D}_{3}$.

\section{Materials and methods}

\section{Animals}

NOD mice that were originally obtained from Professor $\mathrm{Wu}$ (1990, Beijing, China), were bred in our animalium (Proefdierencentrum Leuven) and kept under conventional conditions. Animals were fed a low-calcium, vitamin D replete diet $(0.2 \%$ calcium, $1 \%$ phosphate, $2000 \mathrm{U}$ vitamin D/kg; Hope Farms, Woerden, The Netherlands). C3H and C57B1/6 mice were purchased from Charles River (Wiga, Sulzfeld, Germany). Diabetes incidence at the age of 200 days in stock mice at the time of the study was $57 \%$ in female and $22 \%$ in male mice. After the age of 200 days, the diabetes incidence in the colony was less than $0.5 \%$. In this study only female NOD mice were used.

\section{Treatment regimen}

$1,25(\mathrm{OH})_{2} \mathrm{D}_{3}$ was kindly provided by M. Uskokovic (HoffmanLa Roche, Nutley, NJ, USA) and was dissolved in arachis oil. Animals were divided into two groups: test animals $(n=40)$ received $1,25(\mathrm{OH})_{2} \mathrm{D}_{3}(5 \mu \mathrm{g} / \mathrm{kg})$ in $0.05 \mathrm{ml}$ arachis oil intraperitoneally every other day, while the control group $(n=40)$ received arachis oil $(0.05 \mathrm{ml})$ only. Treatment was started at the age of 21 days and terminated at the age of 200 days or on the day of diabetes diagnosis.

\section{Evaluation of disease and insulitis}

Mice were weighed weekly and glucosuria was tested three times per week starting from the age of 70 days using Ketodiabur Stix (Boehringer Mannheim, Mannheim, Germany). Diabetes was diagnosed in mice having positive glucosuria and glycaemia above $13.8 \mathrm{mmol} / \mathrm{l}$ on two consecutive days. Glycaemia was measured on a Glucoscot II Glucometer (Menarini, Firenze, Italy). Due to injection accidents, four $1,25(\mathrm{OH})_{2} \mathrm{D}_{3}$ treated mice $(10 \%)$ and eight of the control mice $(20 \%)$ died. These mice were excluded from evaluation. At diabetes diagnosis or at 200 days of age, mice were killed by ether inhalation and cervical dislocation ( $24 \mathrm{~h}$ after the final injection). Pancreata were removed, fixed in Bouin's solution, embedded in paraffin and serial sections of the whole pancreas were made. Sections were stained with haematoxylin eosin. Insulitits was evaluated by two independent investigators. A mean of 30 islets per pancreas were screened and the level of lymphocytic infiltration in the islets was scored as described previously [19]. Briefly, the following scoring system was used: 0 , no lymphocytes in or around the islets; 1 , periductular infiltrate; 2 , peri-islet infiltrate; 3 , intraislet infiltrate; 4 , intra-islet infiltrate associated with beta-cell destruction. The mean score for each pancreas was calculated by dividing the total score by the number of islets scored. Any degree of lymphocytic infiltration $(>0)$ was scored as positive.

\section{Evaluation of calcaemic effects of $1,25(\mathrm{OH})_{2} \mathrm{D}_{3}$}

At the age of 200 days or at diabetes diagnosis, blood was taken by heart puncture. Calcium was determined by microcolorimetric assay (Sigma, St. Louis, Mo., USA) and serum osteocalcin was determined by an in-house radioimmunoassay that used mouse osteocalcin as standard and a polyclonal guinea pig antimouse osteocalcin antiserum. The within and between assay variation coefficients were 4 and $6 \%$, respectively, and the sensitivity was $0.02 \mathrm{nmol} / \mathrm{l}$ (R. Bouillon, unpublished observations). Calcium content in the tibia was measured as calcium in bone ash dilutions as described previously [20].

\section{Immunological tests}

Mixed lymphocyte reaction: spleens were removed aseptically, gently teased apart and pressed through a steel mesh. Splenocytes of test animals $\left(5 \times 10^{6} / \mathrm{ml} ; 5 \times 10^{5}\right.$ cells per well) were cocultured after T-cell enrichment by nylon wool passage with irradiated (3000 $\mathrm{Rad},{ }^{60} \mathrm{Co}$ source) splenocytes from $\mathrm{C} 57 \mathrm{~B} 1 / 6$ mice as stimulators $\left(5 \times 10^{6} / \mathrm{ml} ; 5 \times 10^{5}\right.$ cells per well $)$ in RPMI 1640 medium (Gibco, Paisley, UK) supplemented with $10 \%$ fetal calf serum, glutamine, $100 \mathrm{U} / \mathrm{ml}$ penicillin, $100 \mu \mathrm{g} / \mathrm{ml}$ streptomycin and $0.2 \%$ mercapto-ethanol for 5 days. Cells were cultured in triplicate in flat-bottomed 96-well microtitre tissue culture plates (Nunc, Roskilde, Denmark). Cells were pulsed after 4 days with $1 \mu \mathrm{Ci}$ of [methyl-3H]thymidine (Radiochemical Center Amersham, Buckinghamshire, UK), harvested $18 \mathrm{~h}$ later on glass filter paper and counted. Stimulation index was calculated according to the following formula:

$\mathrm{SI}=\mathrm{cpm}($ responders + stimulators $) / \mathrm{cpm}($ responders $) \times 100$.

\section{Anti-CD3 stimulation}

Splenocytes $\left(1 \times 10^{6} / \mathrm{ml} ; 2 \times 10^{5}\right.$ cells per well) or thymocytes $\left(1 \times 10^{6} / \mathrm{ml} ; 2 \times 10^{5}\right.$ cells per well $)$ were cultured in RPMI 1640 medium supplemented with $10 \%$ fetal calf serum, glutamine, $100 \mathrm{U} / \mathrm{ml}$ penicillin, $100 \mu \mathrm{g} / \mathrm{ml}$ streptomycin and $0.2 \%$ mercapto-ethanol. Cells were cultured in triplicate in flat-bottomed 96 well microtitre tissue culture plates (Nunc, Roskilde, Denmark) in the presence of soluble anti-CD3 monoclonal antibody $(17 \mu \mathrm{g} / \mathrm{ml})$ (a kind gift of J. Plum, University of Ghent, Belgium) for $72 \mathrm{~h}$. [Methyl-3H]thymidine incorporation was measured after $18 \mathrm{~h}$ and SI were calculated.

\section{Natural killer cell activity}

As target cells YAC-1 tumour cells (ATCC) were used. For labelling, $1 \times 10^{6} \mathrm{YAC}-1$ cells were resuspended in $0.4 \mathrm{ml}$ RPMI 1640 with $5 \%$ fetal calf serum and $200 \mu \mathrm{Ci}{ }^{51} \mathrm{Cr}$ (Radiochemical Center) and incubated at $37^{\circ} \mathrm{C}$ for $60 \mathrm{~min}$ in a $\mathrm{CO}_{2}$ incubator. Thereafter target cells were washed three times and 


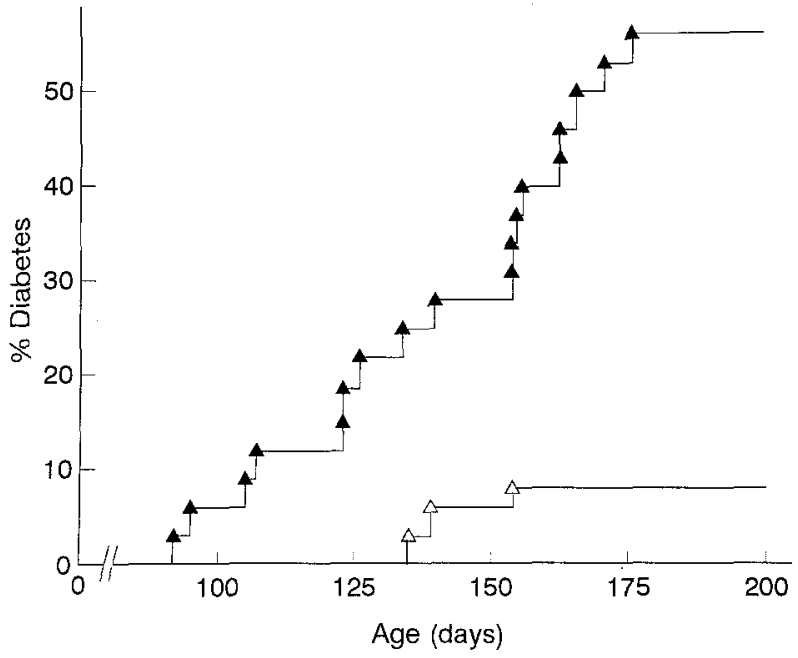

Fig. 1. Cumulative incidence of diabetes in female NOD mice. Mice were tested three times weekly for glucosuria and were considered diabetic when having positive glucosuria and blood glucose $>13.8 \mathrm{mmol} / \mathrm{l}$ on 2 consecutive days. $\triangle, 1,25(\mathrm{OH})_{2} \mathrm{D}_{3}$ group $(n=36) ; \boldsymbol{\Delta}$, arachis oil treated group $(n=32)$. Statistical analysis was performed using chi-square test $(p<0.001)$

Table 1. Effects of $1,25(\mathrm{OH})_{2} \mathrm{D}_{3}$ on calcium metabolism

\begin{tabular}{llcl}
\hline & $\begin{array}{l}\text { Calcium } \\
(\mathrm{mmol} / \mathrm{l})\end{array}$ & $\begin{array}{l}\text { Osteocalcin } \\
(\mathrm{nmol} / \mathrm{l})\end{array}$ & $\begin{array}{l}\text { Bone calcium } \\
\text { (mg/tibia) }\end{array}$ \\
\hline Control & $2.2 \pm 0.2$ & $9.3 \pm 1.4$ & $6.2 \pm 1.1$ \\
$(n=32)$ & $p<0.005$ & $p<0.001$ & $p<0.01$ \\
$\begin{array}{l}1,25(\mathrm{OH})_{2} \mathrm{D}_{3} \\
(n=36)\end{array}$ & $2.5 \pm 0.2$ & $17.2 \pm 5.7$ & $2.9 \pm 0.6$ \\
\end{tabular}

On day 200 or the day of diabetes diagnosis, animals were bled by heart puncture. Serum calcium and osteocalcin were determined as well as bone calcium content per tibia, as described in Materials and methods. Mean values \pm SD are shown

were adjusted to a concentration of $1 \times 10^{5}$ cells per $\mathrm{ml}$ in $10 \mathrm{ml}$ RPMI 1640 with $10 \%$ fetal calf serum, glutamine, $100 \mathrm{U} / \mathrm{ml}$ penicillin and $100 \mu \mathrm{g} / \mathrm{ml}$ streptomycin.

Splenocytes $\left(5 \times 10^{6} / \mathrm{ml} ; 5 \times 10^{5}\right.$ per well $)$ were added as effector cells to $1 \times 10^{451} \mathrm{Cr}$-labelled target cells in a final volume of $0.2 \mathrm{ml}$ of RPMI 1640 with $10 \%$ fetal calf serum, glutamine, $100 \mathrm{U} / \mathrm{ml}$ penicillin and $100 \mu \mathrm{g} / \mathrm{ml}$ streptomycin per well (effector: target ratio 50:1). Cells were cultured in quadruplicate in 96well V-bottom microtitre plates (Nunc) for $4 \mathrm{~h}$ at $37^{\circ} \mathrm{C}$ in a $\mathrm{CO}_{2}$ incubator. ${ }^{51} \mathrm{Cr}$ release was measured in the supernatant. Spontaneous release of ${ }^{51} \mathrm{Cr}$ was obtained by monitoring radioactivity released during the incubation of $1 \times 10^{4}$ target cells alone. Maximum release of ${ }^{51} \mathrm{Cr}$ was determined by monitoring radioactivity released after the addition of a detergent (saponin) to lyse the target cells. Percent of specific lysis was calculated according to the following formula: percent specific lysis $=[(\mathrm{CPM}$ experimental - CPM spontaneous release $) /(\mathrm{CPM}$ maximum release - CPM spontaneous release $)] \times 100$.

\section{Suppressor cell assay}

The capacity to generate suppressor cells in an autologous MLR was tested as described previously [21]. Briefly, T cells $\left(5 \times 10^{6} / \mathrm{ml} ; 5 \times 10^{5}\right.$ per well $)$ from the test animal, enriched from splenocytes by nylon wool passage, were co-cultured with ${ }^{60} \mathrm{Co}$ irradiated (3000 Rad) splenic leucocytes from the same animal $\left(5 \times 10^{6} / \mathrm{ml} ; 5 \times 10^{5}\right.$ per well $)$, in RPMI 1640 medium supplemented with $10 \%$ fetal calf serum, glutamine, $100 \mathrm{U} / \mathrm{ml}$ penicillin, $100 \mu \mathrm{g} / \mathrm{ml}$ streptomycin and $0.2 \%$ mercapto-ethanol in triplicate in flat-bottomed 96-well microtitre plates. Concurrently, bulk cultures consisting of $5 \times 10^{6}$ test responder T cells and $5 \times 10^{6}$ test stimulator splenocytes were established in upright $25-\mathrm{cm}^{2}$ culture flasks. On day 6 [methyl-3H]thymidine incorporation in the microtitre plate was measured, while viable T cells $\left(5 \times 10^{6} / \mathrm{ml} ; 5 \times 10^{5}\right.$ per well) recovered from the bulk cultures were tested for their capacity to suppress the blastogenic response of freshly isolated control NOD T cells to irradiated C57B1/6 stimulators in a 4-day MLR, following the protocol for MLR as described above. $\mathrm{C} 3 \mathrm{H}$ mice, known to have normal suppressor activity, were also included as control animals. Suppressor activity of T cells recovered from bulk cultures was expressed as \% suppression:

mean $\Delta \mathrm{cpm}$ of the unsuppressed MLR-mean $\Delta \mathrm{cpm}$ of the suppressed response

mean cpm of the unsuppressed response $\times 100$

\section{Cell transfer experiments}

For diabetes transfer, naïve 6-8-week-old male NOD mice, were irradiated ( $750 \mathrm{Rad}$ ) and, $48 \mathrm{~h}$ after irradiation received $20 \times 10^{6}$ splenocytes, obtained as described above, from overtly diabetic NOD mice i.v. In co-transfer experiments, $20 \times 10^{6}$ splenocytes from animals treated with $1,25(\mathrm{OH})_{2} \mathrm{D}_{3}$ up to the age of 200 days or from arachis-oil-treated control mice of similar age, were injected i.v., $24 \mathrm{~h}$ prior to the transfer of the diabetogenic cells. Mice were tested for glucosuria twice weekly and were considered diabetic following the above-described criteria.

\section{Statistical analysis}

Data are expressed as mean \pm SD. Comparison of the incidence of insulitis and diabetes between the two groups was performed using the chi-square test. Significance of differences between the groups concerning calcaemic effects immunological data were calculated using the Mann Whitney U-test or, for normally distributed data, the unpaired Student's $t$-test. Significance was defined at the 0.05 level.

\section{Results}

Prevention of insulitis and diabetes by $1,25(\mathrm{OH})_{2} \mathrm{D}_{3}$. Confirming previous results, treatment with $1,25(\mathrm{OH})_{2} \mathrm{D}_{3}$ succeeded in reducing insulitis incidence from $81 \%$ (26 of 32 mice) in the control group to $58 \%$ (21 of 36 mice) in the treated group $(p<0.05)$. Animals with as few as one pathological islet were considered to have insulitis. Also, the severity of inflammation in the islets of treated mice $(2.1 \pm 1.4)$ was less than in the control group $(3.2 \pm 1.4 ; p<0.025)$. Treatment with $1,25(\mathrm{OH})_{2} \mathrm{D}_{3}$ not only reduced insulitis incidence, but more importantly also reduced the cummulative incidence of diabetes at the age of 200 days, from $56 \%$ (18 of 32 mice) in the control group to $8 \%$ ( 3 of 36 mice) in 
Table 2. Influence of long-term $1,25(\mathrm{OH})_{2} \mathrm{D}_{3}$ therapy on cellular immunity

\begin{tabular}{|c|c|c|c|c|}
\hline \multirow[t]{2}{*}{ Groups } & \multirow[t]{2}{*}{ MLR (SI) } & \multicolumn{2}{|c|}{ Anti-CD3 (SI) } & \multirow{2}{*}{$\begin{array}{l}\text { YAC-1 killing } \\
(\%)\end{array}$} \\
\hline & & splenocytes & thymocytes & \\
\hline $\begin{array}{l}\text { Control } \\
(n=32)\end{array}$ & $\begin{array}{l}33.0 \pm 29.8 \\
\text { NS }^{a}\end{array}$ & $\begin{array}{l}51.2 \pm 48.2 \\
\mathrm{NS}^{\mathrm{a}}\end{array}$ & $\begin{array}{l}5.4 \pm 5.6 \\
\mathrm{NS}^{\mathrm{a}}\end{array}$ & 0 \\
\hline $\begin{array}{l}1,25(\mathrm{OH})_{2} \mathrm{D}_{3} \\
(n=36)\end{array}$ & $47.8 \pm 76.6$ & $38.0 \pm 14.9$ & $5.8 \pm 4.3$ & 0 \\
\hline
\end{tabular}

At 200 days, splenocytes from control NOD mice $(n=15)$ and $1,25(\mathrm{OH})_{2} \mathrm{D}_{3}$ treated NOD mice $(n=27)$ were tested in MLR, anti-CD3 stimulation and YAC-1 target killing. Thymocytes were only tested in anti-CD3 stimulation assays.

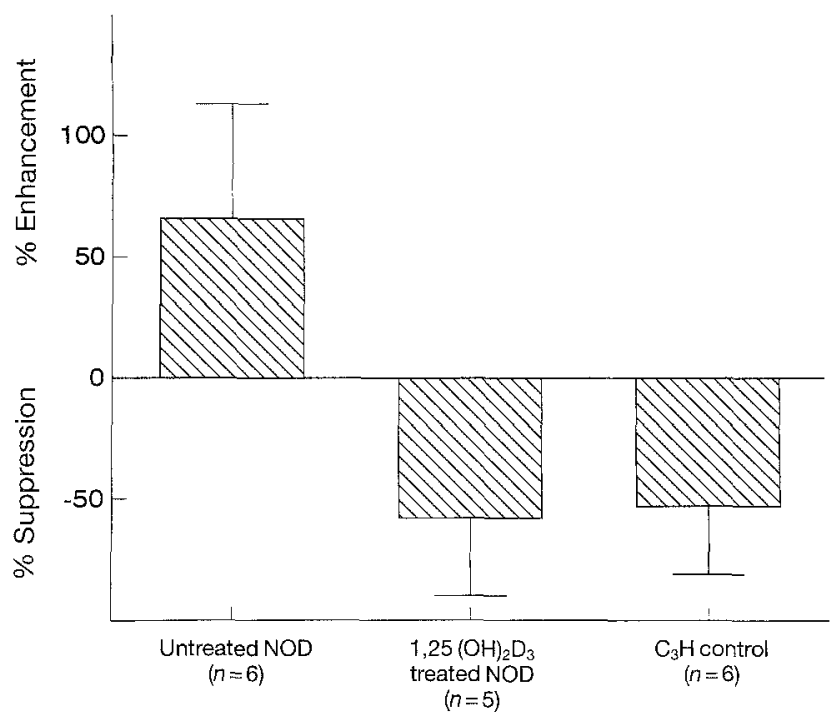

Fig. 2. Suppression of allogeneic MLR by suppressor cells generated in autologous MLR. When addition of putative suppressor cells did not result in suppression, but in stimulation of the read-out MLR, this was expressed as \% enhancement. Mean values $\pm \mathrm{SD}$ are shown. Number of experiments is shown in parentheses. Statistical analysis was performed by using the Mann Whitney U-test $\left[p<0.05\right.$, control NOD vs $1,25(\mathrm{OH})_{2} \mathrm{D}_{3}$ treated NOD]

the treated group $(p<0.001)$ (Fig. 1). The three mice that developed diabetes despite treatment with $1,25(\mathrm{OH})_{2} \mathrm{D}_{3}$, did so later than the control animals.

General tolerance and effects on calcium metabolism. All animals had good fur quality and were thriving. All mice were weighed weekly and no difference was seen in weight gain between the $1,25(\mathrm{OH})_{2} \mathrm{D}_{3}$ and the vehicle-treated group resulting in a similar weight at the age of 200 days (data not shown). As expected, calcaemia, determined $24 \mathrm{~h}$ after the final injection of $1,25(\mathrm{OH})_{2} \mathrm{D}_{3}(n=36)$ was raised $(2.5 \pm 0.2$ vs $2.2 \pm$ $0.2 \mathrm{mmol} / \mathrm{l}$ in the control group $[n=32], p<0.005$ ) (Table 1), but remained in the normal range. Also osteocalcin, a vitamin $\mathrm{D}$ dependent calcium binding protein reflecting bone turnover, was clearly elevated in the $1,25(\mathrm{OH})_{2} \mathrm{D}_{3}$ treated group $(n=36)(17.2 \pm 5.7 \mathrm{vs}$ $9.3 \pm 1.4 \mathrm{nmol} / \mathrm{l}$ in the control group $[n=32], p<$ $0.001)$. Although these high doses of $1,25(\mathrm{OH})_{2} \mathrm{D}_{3}$
Mean values $\pm S D$ are shown.

${ }^{a}$ No statistical difference was present between the groups

were apparently well tolerated and allowed for longterm treatment, the universal effects on bone were severe as reflected by a $50 \%$ decrease in calcium content of the tibias of the $1,25(\mathrm{OH})_{2} \mathrm{D}_{3}$ treated mice $(n=$ 36) $[2.9 \pm 0.6 \mathrm{vs} 6.2 \pm 1.1 \mathrm{mg}$ calcium/tibia in the control group $(n=32)$, (mean $\pm \mathrm{SD}) p<0.01]$. This bone demineralisation resulted in a spontaneous femur fracture in one test animal.

Effects of $1,25(\mathrm{OH})_{2} \mathrm{D}_{3}$ on the immune system. In order to understand the immune effects and potential mechanisms of action of long-term treatment with high doses of $1,25(\mathrm{OH})_{2} \mathrm{D}_{3}$, immunological tests were performed at the age of 200 days in both treated and control nondiabetic mice $24 \mathrm{~h}$ after the final injection of $1,25(\mathrm{OH})_{2} \mathrm{D}_{3}$ or arachis oil. Fluorescence activated cell sorting analysis of lymphocyte subsets (T lymphocytes, CD4, CD8, B-lymphocytes, NK cells) in spleen, thymus and lymph nodes revealed no significant differences in relative or absolute numbers between the two groups (markers analysed were Thy1.2, Lyt2, L3T4 (Becton Dickinson, Erenbodegem, Belgium), IgG + IgM (Jackson Labs, West Grove, Pa., USA) and ASGM-1 (Wako Chemicals, Neuss, Germany), respectively (data not shown). Although $1,25(\mathrm{OH})_{2} \mathrm{D}_{3}$ is a potent inhibitor of T-cell proliferation in vitro, long-term administration of $1,25(\mathrm{OH})_{2} \mathrm{D}_{3}$ in vivo did not result in severe immunosuppression, since splenocytes from both groups were able to proliferate normally in the allogeneic MLR as well as after anti-CD3 stimulation (Table 2). Some known immune defects of NOD mice, such as defective NK-cell killing of YAC-1 targets [22] or defective thymocyte activation by anti-CD3 [23] were not corrected by $1,25(\mathrm{OH})_{2} \mathrm{D}_{3}$ therapy.

The suppressor cell assay yielded the most interesting results: whereas control NOD mice could not generate suppressor cells in an autologous MLR, another known immune defect of the NOD mouse [21], we observed a complete normalisation of suppressor activity in the $1,25(\mathrm{OH})_{2} \mathrm{D}_{3}$ treated mice (Fig. 2). The existence of suppressor cells was moreover confirmed in cell transfer experiments. Cotransfer of splenocytes from $1,25(\mathrm{OH})_{2} \mathrm{D}_{3}$ treated animals significantly delayed and almost completely blocked diabetes transfer into naïve irradiated young male NOD mice $(p<0.001$ 


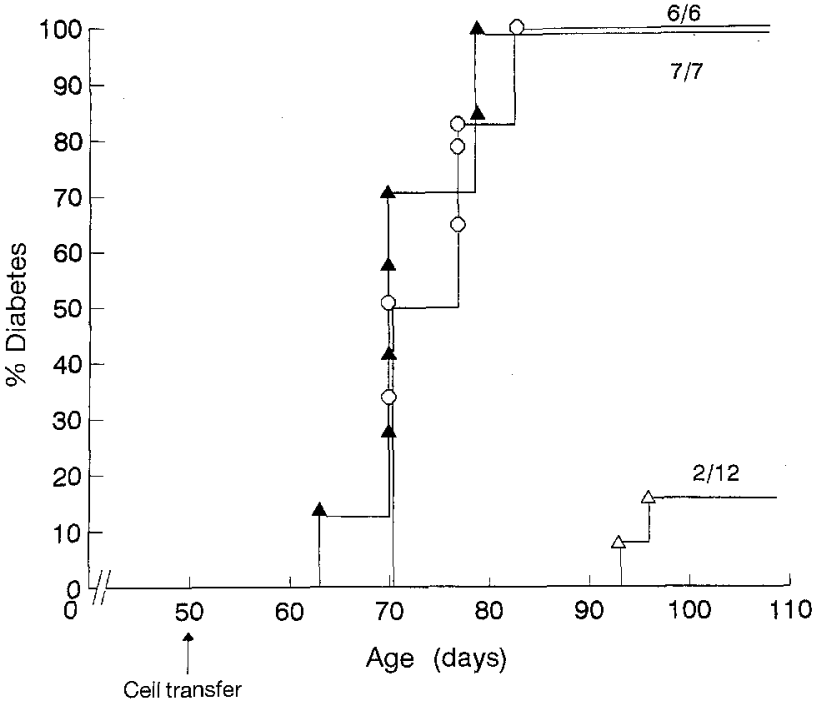

Fig. 3. Protective effect of splenocytes from $1,25(\mathrm{OH})_{2} \mathrm{D}_{3}$ treated NOD mice against diabetes transfer. Mice (6-8 week, irradiated $750 \mathrm{Rad})$ receiving only splenocytes $\left(20 \times 10^{6} \mathrm{iv}\right)$ from overtly diabetic NOD mice $(\boldsymbol{\Delta})$ developed diabetes within 4 weeks after transfer $(n=7)$. No protective effect was seen when co-transfer was performed with splenocytes $\left(20 \times 10^{6} \mathrm{iv}\right)$ from normoglycaemic control mice $(n=6)(0, \mathrm{NS})$. Co-transfer with splenocytes from $1,25(\mathrm{OH})_{2} \mathrm{D}_{3}$ treated mice $(n=12)$, however, protected in the majority of cases against diabetes $(\triangle$, $p<0.0001)$ demonstrating the existence of suppressor cells in these $1,25(\mathrm{OH})_{2} \mathrm{D}_{3}$ treated mice

vs controls). Cotransfer with splenocytes from normoglycaemic age-matched (200 days) control NOD mice had no effect (Fig.3).

\section{Discussion}

The NOD mouse is a well-known animal model for the study of autoimmune diabetes (juvenile diabetes or IDDM). This autoimmune disease is characterized in mice and man by an infiltration of the islets of Langerhans in the pancreas resulting in a selective destruction of the insulin-producing beta cells. The cause of this insulitis and consequent diabetes is unknown, but in analogy with other autoimmune diseases, apart from faulty central tolerance induction, due to defective negative selection during T-cell development, and inaccurate anergy induction, disruption of the balance between autoreactive cytotoxic T-cell clones and suppressor mechanisms (suppressor T cells) is an acceptable hypothesis [1-4]. Indeed, prevention of autoimmune diabetes in NOD mice can be achieved on the one hand by immunosuppressive treatments such as cyclosporin, FK 506, anti-lymphocyte serum or anti-L3T4 monoclonal antibodies [24-27], but on the other hand, also by immunostimulation, probably by restoring defective suppressor mechanisms [28].

Both capacities, inhibition of effector $T$ cells and stimulation of suppressor functions, have been at- tributed to $1,25(\mathrm{OH})_{2} \mathrm{D}_{3}$ the active form of vitamin $\mathrm{D}$, making this drug an ideal tool in the prevention of autoimmunity.

$1,25(\mathrm{OH})_{2} \mathrm{D}_{3}$ is a powerful immunosuppressive drug in vitro, resulting in inhibition of effector T-cell proliferation and lymphokine production (interleukin2 , interferon- $\gamma$, tumour necrosis factor- $\alpha$ ). It stimulates, however, monocyte differentiation and macrophage function and enhances suppressor function [29-30]. In vivo, $1,25(\mathrm{OH})_{2} \mathrm{D}_{3}$ is able to prevent certain autoimmune diseases (experimental allergic encephalomyelitis, arthritis, thyroiditis) [31], but use of the drug is limited by its hypercalcaemic effects. In a pilot study, we demonstrated that treatment with high doses of $1,25(\mathrm{OH})_{2} \mathrm{D}_{3}\left(5 \mu \mathrm{g} \cdot \mathrm{kg}^{-1} \cdot 2 \mathrm{day}^{-1}\right)$ could be tolerated under certain conditions and was able to significantly reduce the incidence of insulitis in NOD mice [19].

The present study had a double purpose. First, toevaluate the potential of $1,25(\mathrm{OH})_{2} \mathrm{D}_{3}$ in the prevention of diabetes itself in NOD mice and secondly, to investigate the effects of long-term treatment with pharmacological doses of $1,25(\mathrm{OH})_{2} \mathrm{D}_{3}$ on the immune system.

Confirming previous results, $1,25(\mathrm{OH})_{2} \mathrm{D}_{3}$ reduced the incidence of insulitis significantly, but more importantly, clinical diabetes was even more drastically reduced.

Extensive immunological testing demonstrated again the short-term immunosuppressive action of $1,25(\mathrm{OH})_{2} \mathrm{D}_{3}$, since splenocytes of treated mice showed a normal response to alloantigen (tested in MLR) and to anti-CD3 stimulation, when tested $24 \mathrm{~h}$ after the final $1,25(\mathrm{OH})_{2} \mathrm{D}_{3}$ injection. This absence of long lasting immunosuppression, partly due to the fast metabolic clearance of the drug, could offer important advantages in clinical application, e.g. during intercurrent infections.

The most striking effect of $1,25(\mathrm{OH})_{2} \mathrm{D}_{3}$ was the complete normalisation of the suppressor activity in treated NOD mice. Whereas control mice showed a failure to generate suppressor cells in autologous MLR, a known defect in NOD mice, suppressor function became normal under treatment with $1,25(\mathrm{OH})_{2} \mathrm{D}_{3}$ [21]. This capacity of $1,25(\mathrm{OH})_{2} \mathrm{D}_{3}$ to enhance the generation of suppressor cells has already been previously demonstrated in vitro [14] and interestingly, this ability to generate suppressor cells has also been reported for cyclosporin A, another immunomodulatory drug, known to prevent diabetes [32]. As demonstrated by Hess et al. [32] addition of cyclosporin to an allogeneic MLR hampers T-cell proliferation, but cannot completely block it and allows for the development of suppressor cells. NOD mice and other mouse strains prone to autoimmunity are unable to mount such suppressor cells in autologous MLR. Serreze et al. [28] demonstrated that by restoring this suppressor capacity, e.g. through treatment of these NOD mice with interleukin- 2 or Poly IC, diabetes could be prevented. The authors suggested that these sup- 
pressor mechanisms may be natural suppressor cells, elicited by an increased macrophage function and increased interleukin- 1 production. The data on the effects of $1,25(\mathrm{OH})_{2} \mathrm{D}_{3}$ on macrophage accessory cell function and monokine production, especially interleukin-1, are somewhat confusion since some studies reported stimulation and others inhibition of interleukin-1 secretion $[15,16,33]$. In our study no statistical difference could be demonstrated in the PS induced interleukin-1 secretion of peritoneal macrophages in both groups (data not shown).

Further evidence for the direct importance of such suppressor cells in the prevention of diabetes can be found in transfer experiments. In previous experiments co-transfer of splenocytes from young non-diabetic male donors suppress the transfer of diabetes by splenocytes from diabetic NOD donors into healthy receptor NOD mice $[34,35]$. Our transfer experiments, where splenocytes from $1,25(\mathrm{OH})_{2} \mathrm{D}_{3}$ treated animals were used in co-transfer with splenocytes from overtly diabetic NOD mice, confirm the existence of these suppressor cells in the $1,25(\mathrm{OH})_{2} \mathrm{D}_{3}$ treated mice, since transfer of diabetes could not only be delayed, but almost completely be prevented. Presently, experiments are being carried out to define the nature of the protective cell ( $\mathrm{T}$ cell/non-T cell).

A major problem, when using $1,25(\mathrm{OH})_{2} \mathrm{D}_{3}$ in vivo, remains the effect on calcium metabolism. Although these high doses of $1,25(\mathrm{OH})_{2} \mathrm{D}_{3}$ did not result in severe hypercalcaemia, they had clear effects on bone turnover. This problem can be overcome by replacing $1,25(\mathrm{OH})_{2} \mathrm{D}_{3}$ by synthetic analogues with decreased calcaemic effects. Indeed, some non-calcaemic analogues with enhanced immunological effects have been developed and are being tested in models of autoimmunity [36-40]. Preliminary results in NOD mice show that some analogues can prevent insulitis and diabetes and even recurrence of diabetes after islet transplantation (unpublished personal data). At this moment of course no conclusions can be drawn for the human situation and therefore the use of $1,25(\mathrm{OH})_{2} \mathrm{D}_{3}$ or its analogues for the prevention of autoimmunity in humans would be at present premature.

We conclude that $1,25(\mathrm{OH})_{2} \mathrm{D}_{3}$ can prevent IDDM in NOD mice, probably by restoring defective suppressor mechanisms, an immune defect involved in the pathogenesis of IDDM in NOD mice. The use of $1,25(\mathrm{OH})_{2} \mathrm{D}_{3}$ as an immunomodulator is however limited by the important effects on calcium metabolism, but new structural analogues of $1,25(\mathrm{OH})_{2} \mathrm{D}_{3}$ with increased immunomodulating and low calcaemic activity may well be candidate drugs for the prevention of autoimmune diseases.

Acknowledgements. We thank Ms. D.Brabants for secretarial expertise in preparing this manuscript. This work was supported by the Belgian National Foundation for Scientific Research: FGWO grant $n^{\circ} 3.0044 .89$ (R. Bouillon) and a N.F. W. O. fellowship (C. Mathieu).

\section{References}

1. Makino S, Kunimoto K, Muraoka Y et al. (1980) Breeding of a non-obese diabetic strain of mice. Exp Anim 29:1-13

2. Castano L, Eisenbarth G (1990) Type I diabetes. A chronic autoimmune disease of humans, mouse and rat. Annu Rev Immunol 8: 647-679

3. Lampeter F, Signore A, Gale E, Pozzilli P (1989) Lessons from the NOD mouse for the pathogenesis and immunotherapy of human type I (insulin-dependent) diabetes mellitus. Diabetologia. 32: 703-708

4. Rossini AA, Greiner DL, Friedman HP, Mordes JP (1993) Immunopathogenesis of diabetes mellitus. Diabetes Rev 1(1): 43-75

5. Hewison M (1992) Vitamin D and the immune system. J Endocrinol 132: 173-175

6. Rigby WFC (1988) The immunobiology of vitamin D. Immunol Today 9: 54-58

7. Provvedini DM, Manolagas SC, Deftos LJ (1983) 1,25-dihydroxyvitamin D3 receptors in human leukocytes. Science 221: $1181-1183$

8. Provvedini DM, Manolagas SC (1989) 1,25 dihydroxyvitamin D3 receptor distribution and effects in subpopulations of normal human T lymphocytes. J Clin Endocrinol Metab 68: 774-779

9. Bhalla A, Amento E, Serog B, Glimcher L (1984) 1,25-Dihydroxy-vitamin D3 inhibits antigen-induced $T$ cells activation. J Immunol 133: 1748-1755

10. Rigby WFC, Denome S, Fanger NW (1987) Regulation of lymphokine production and human T lymphocyte activation by 1,25 dihydroxy-vitamin D3. J Clin Invest 79: 16591664

11. Rigby WFC, Yirinec B, Oldershaw RL, Fanger MW (1987) Comparison of the effects of 1,25 dihydroxyvitamin D3 on T lymphocyte subpopulations. Eur J Immunol 17: 563-566

12. Reichel H, Koeffler HP, Tobler A, Norman AW (1987) $1 \alpha$, 25-Dihydroxyvitamin D3 inhibits gamma-interferon synthesis by normal human peripheral blood lymphocytes. Proc Natl Acad Sci USA 84: 3385-3391

13. Saggese G, Federico G, Balestri M, Torriolo A (1989) Calcitriol inhibits the PHA-induced production of IL-2 and IFNgamma and the proliferation of human peripheral blood leukocytes while enhancing the surface expression of HLA class II molecules. J Endocrinol Invest 12:329-335

14. Meehan MA, Kerman RH, Lemire JM (1992) 1,25-Dihydroxyvitamin D3 enhances the generation of non specific suppressor cells while inhibiting the induction of cytotoxic cells in a human MLR. Cell Immunol 140: 400-409

15. Lemire JM (1992) Immunomodulatory role of 1,25-dihydroxyvitamin D3. J Cell Biochem 49: 26-31

16. Rigby WFC, Waugh MG (1992) Decreased accessory cell function and costimulatory activity by 1,25 -dihydroxyvitamin D3-treated monocytes. Arthritis Rheum 35: 110-119

17. Fournier C, Gepner P, Sadouk M, Charriere J (1990) In vivo beneficial effects of cyclosporin $A$ and 1,25-dihydroxyvitamin D3 on the induction of experimental autoimmune thyroiditis. Clin Immunol Immunopathol 54: 53-63

18. Lemire J, Archer C (1991) 1,25-Dihydroxyvitamin D3 prevents the in vivo induction of murine experimental autoimmune encephalomyelitis. J Clin Invest 87: 1103-1107

19. Mathieu C, Laureys J, Sobis H, Vandeputte M, Waer M, Bouillon R (1992) 1,25-Dihydroxyvitamin D3 prevents insulitis in NOD mice. Diabetes 41(11): 1491-1495

20. Verhaeghe J, Bouillon R, Lissens W, Visser WJ, Van Assche FA (1988) Diabetes and low Ca-P diet have opposite effects on adult and fetal bone mineral metabolism. Am J Physiol 254: E496-E504 
21. Serreze DV, Leiter EH (1988) Defective activation of T suppressor cell function in nonobese diabetic mice. J Immunol 140(11): 3801-3807

22. Kataoka S, Satoh J, Fujiya H et al. (1983) Immunological aspects of the nonobese diabetic (NOD) mouse. Abnormalities of cellular immunity. Diabetes 32: 247-253

23. Zipris D, Lazarus AH, Crow AR, Hadzija M, Delovitch TL (1991) Defective thymic T cell activation by concanavalin A and anti-CD3 in autoimmune nonobese diabetic mice. J Immunol 146: 3763-3771

24. Harrada M, Makino S (1986) Suppression of overt diabetes in NOD mice by anti-thymocyte serum or anti-Thy 1.2 antibody. Exp Anim 35: 501-504

25. Koike T, Itoh Y, Ishii T et al. (1987) Preventive effect of monoclonal anti-L3T4 antibody on the development of diabetes in NOD mice. Diabetes 36: 539-541

26. Mori Y, Suko M, Okudaira H et al. (1986) Preventive effects of cyclosporine on diabetes in NOD mice. Diabetologia 29: 244-247

27. Miyagawa J, Yamamoto K, Hanafusa T et al. (1990) Preventive effect of a new immunosuppressant FK-506 on insulitis and diabetes in non-obese diabetic mice. Diabetologia 33: 503-505

28. Serreze DV, Hamaguchi K, Leiter EH (1989) Immunostimulation circumvents diabetes in NOD/Lt mice. J Autoimmunity 2: 759-776

29. Manolagas SC, Hustmeyer FG, Yu XP (1990) Immunomodulating properties of 1,25-dihydroxyvitamin D3. Kidney Int 38 [Suppl 29]: S9-S16

30. Walters MR (1992) Newly identified actions of the vitamin D endocrine system. Endocrine Res 13: 719-764

31. Bikle DD (1992) Clinical counterpart: vitamin D: new actions, new analogs, new therapeutic potential. Endocrine Res 13: 765-784

32. Hess AD, Donnenberg AD, Tutschka PJ, Santos G (1983) Effects of cyclosporin A on human lymphocyte response in vitro. J Immunol 130(2): 717-721
33. Zarrabeitia MT, Riancho JA, Amado JA, Olmos JM, Gonzalez-Macias J (1992) Effect of calcitriol on the secretion of prostaglandin E2, IL-1 and tumor necrosis factor alpha by human monocytes. Bone 13(2): 185-189

34. Hutchings PR, Cooke A (1990) The transfer of autoimmune diabetes in NOD mice can be inhibited or accelerated by distinct cell populations present in normal splenocytes taken from young males. J Autoimmunity 3: 175-185

35. Boitard C, Yasunami R, Dardenne M, Bach JF (1989) T cell mediated inhibition of the transfer of autoimmune diabetes in NOD mice. J Exp Med 169: 1669-1680

36. Binderup L, Bramm E (1988) Effects of a novel vitamin D analogue MC903 on cell proliferation and differentiation in vitro and on calcium metabolism in vivo. Biochem Pharmacol 37: 889-895

37. Bouillon R, Allewaert K, Xiang DZ, Tan BK, Van Baelen H (1991) Vitamin $D$ analogs with low affinity for the vitamin $D$ binding protein: enhanced in vitro and decreased in vivo activity. J Bone Mineral Res 6: 1051-1057

38. Binderup L, Latini S, Kissmeyer AM(1991) New vitamin D3 analogues with potent effects on cell growth regulation and immune responses: structure-activity studies. In: A. W. Norman, R.Bouillon, M.Thomasset (eds) Vitamin D. Gene regulation, structure-function analysis and clinical application. De Gruyter, Berlin, pp. 478-485

39. Latini S, Binderup L (1991) KH1060. A new vitamin D analogue with potent effects on cell-mediated immune responses in vitro. In: A. W. Norman, R. Bouillon, M.Thomasset (eds) Vitamin D. Gene regulation, structure-function analyses and clinical application. De Gruyter, Berlin, pp. 516-519

40. Abe J, Nakamura K, Takita Y, Nakano T, Irie H, Nishii Y (1990) Prevention of immunological disorders in MRL/I mice by a new synthetic analogue of vitamin D3: $220 x a-1 \alpha$, 25-Dihydroxyvitamin D3. J Nutr Sci Vitaminol 36:21-31 